\title{
Inside the Mind of Latin Americas New Right
}

Cannon, Barry . NACLA Report on the Americas ; New York Vol. 48, Iss. 4, (Winter 2016): 328-333.

\author{
¿ProQuest document link
}

\begin{abstract}
In Latin America, the political Right is back. In both Argentina and Brazil, governments led by right-wing presidents have taken power in the last year, after more than a decade of being led by left-leaning parties. Similarly, in Venezuela, an intense battle rages between elements of the Chavista Left and an insurgent Right -- the outcome of which is still unknown. What Despite being perceived by some sections of the left as not radical enough, the "pink tide" governments that rose to power in the region from 1999 onwards, challenged neoliberalism in a variety of arenas. Beginning with the military coup against the government of Salvador Allende in Chile in 1973, the Latin American Right has coalesced around a neoliberal project that is informed by a deeply-held belief that "free" trade, easier and more foreign direct investment, and an economy almost exclusively controlled by the private sector, the markets, and competition are the best way to solve pressing economic or social problems.
\end{abstract}

\section{FULL TEXT}

\section{Headnote}

If the rhetoric of Latin American elites is any evidence, neoliberalism is alive and well, despite a decade and a half of Left governance.

In Latin America, the political Right is back. In both Argentina and Brazil, governments led by right-wing presidents have taken power in the last year, after more than a decade of being led by left-leaning parties. Similarly, in Venezuela, an intense battle rages between elements of the Chavista Left and an insurgent Right-the outcome of which is still unknown. What accounts for the Right's resurgence? How have conservative forces taken back power? What do we know about the social and economic policies right-wing forces will pursue now that they have returned to power? And what options does the Left have in this changing political environment?

In answering these questions, a few things seem clear. The first is that the region's Left governments that came to power starting in the early 2000s-even those that were more moderate in their policy proposals-did, in fact, threaten the neoliberal project that had advanced throughout the 1990s. This realization prompted a bloc of conservative parties and business elites to use a wide variety of strategies to regain power-not just through democratic institutions, but also through the elite-dominated media and the Right's persistent control of key economic structures. In many cases, conservative movements in the region have also enjoyed the firm backing of powerful international allies. At this early stage of its resurgence, the ultimate goal of the Right is to get the neoliberal project back on track, but this time in a way that will be much more difficult to unravel in the future. The urgency of this challenge must prompt an organizational, discursive, and programmatic reassessment on the Left, if it is to be successfully resisted. 
Despite being perceived by some sections of the Left as not radical enough, the "pink tide" governments that rose to power in the region from 1999 onwards, challenged neoliberalism in a variety of arenas. Beginning with the military coup against the government of Salvador Allende in Chile in 1973, the Latin American Right has coalesced around a neoliberal project that is informed by a deeply-held belief that "free" trade, easier and more foreign direct investment (FDI), and an economy almost exclusively controlled by the private sector, the markets, and competition are the best way to solve pressing economic or social problems. The neoliberal project was consolidated across the region through the 1990s, when multiple social and economic crises in the region prompted popular sectors to challenge policies of deregulation and privatization in the face of rising unemployment and poverty. These conditions set the stage for the election of Left governments in much of the region, all of which challenged orthodox neoliberal wisdom, according to the particularities of their national contexts.

In sociological terms, the threat level of the Left's challenge to the neoliberal status quo could be characterized as "low-to-medium" or "medium-to-high," depending on the country under study. Examples of Left government's lowto-medium threat to neoliberalism were seen in Uruguay's Broad Front (Frente Amplio) governments and in the rise of Brazil's Workers' Party (PT) under President Lula da Silva (2002-2010) and subsequently President Dilma Rousseff (2011-2016). In these cases, key policies associated with neoliberalismfrom privatization of national industries to increased market liberalization-were halted or reduced as the state took a more active and interventionist role in the economy. In very few cases, however, were privatized enterprises returned to public ownership. At the same time, relations with the U.S. remained cordial, although national priorities were emphasized. Brazil, in particular, even sought a greater role for Latin America in hemispheric and global politics by helping to found and lead a new regional alliance, UNASUR (the Union of South American Nations), which aimed to one day consolidate a sort of European Union for South America. Similarly, Brazil also played a leading role in forging new South-South alliances, most notably through the so-called BRICS group, with Russia, India, China and South Africa.

In those cases where neoliberalism faced a "mediumto-high" threat, more radical departures from market-based policies were undertaken in a greater number of areas of social and economic concern. This included renationalizations of previously privatized enterprises in critical sectors, like aviation, transport, electricity, and oil and gas development. To a greater or lesser degree, such policies were carried out in Venezuela, Argentina, Bolivia, and Ecuador over the last decade and a half. There Left governments placed stricter controls on the market, including the use of exchange controls (Venezuela and Argentina), limiting the autonomy of national central banks, implementing price controls and carrying out debt defaults (Argentina and Ecuador), and starting land redistribution projects (Bolivia and Venezuela). Such actions went beyond just stalling neoliberalism, instead actively aiming to reverse the neoliberal order in order to install a new "post-neoliberal" model-a sort of transitional model which did not completely dismantle neoliberalism but clearly signaled a rejection of its basic tenets and the desire to find something more socially responsive and inclusive.

Such a project also involved departures from liberal democracy, with its emphasis on representation, and the creation of more participative structures that sought to involve ordinary citizens in day-to-day decision-making. Some Brazilian cities that were led by PT politicians, such as Porto Alegre, became famous in this respect, promoting participatory budgeting processes whereby local residents themselves could decide on city spending priorities. In addition, in Bolivia, Ecuador, and Venezuela, national governments-working closely with social movements-opened the way for new constitutional assemblies that included wide popular participation and resulted in the creation of more participative and socially-inclusive national constitutions. Venezuela stands out in this regard, introducing what it called "communal councils"-that is, a local framework in which citizens obtained an important voice in social policymaking and social policy implementation. 
More radical countries sought to limit the power and freedom of private media as well. This agenda was carried out in three different manners. First, Left governments strengthened existing state broadcasters, increasing their budgets and reach. The Bolivarian countries-namely, Venezuela, Bolivia, and Ecuador- even created, with the support of Cuba, Brazil, and Argentina, a new regional broadcaster, Telesur, which over the last decade became a sort of Al Jazeera for the Latin American and Caribbean region. Second, a variety of laws were introduced by the three Bolivarian governments and by the government of Cristina Fernández de Kirchner in Argentina to attempt to limit concentration of media ownership and increase popular control over media content. Such measures included, for example, the 2004 Law on Social Responsibility of Radio and Television in Venezuela and the 2009 Law on Audiovisual Communication Services in Argentina. Lastly, a third strategy of the Latin American Left was to encourage community ownership of media itself. Once again, Venezuela stands out in this area as the number of community-run media outlets-on radio, television and online-have mushroomed since the 2004 law from a few hundred to thousands.

Military relations also changed under the Left, with Ecuador and Bolivia, in particular, reducing or eliminating cooperation with the United States on issues like counternarcotics and military training. Similarly, while Brazil formed and promoted UNASUR, Venezuela founded, alongside Cuba and Bolivia, the more radically anti-neoliberal Bolivarian Alliance for the Peoples of Our Americas (ALBA). Finally, Left-led countries by and large rejected signing free-trade agreements with the United States. This contrasts sharply with countries where neoliberalism has persisted in the last decade and half, namely in Mexico, Colombia, Peru and Chile. In 2011, these four countries formed the Pacific Alliance (PA), a transnational organization seeking to "move progressively towards the free movement of goods, services, resources, and people," as the Alliance's website explains. Many observers expect that the Pacific Alliance will eventually seek greater integration with U.S. and European markets through new free trade initiatives.

\section{The Right's Response}

Right-wing responses to the Left's emergence have ranged from the use of institutional mechanisms (i.e. the formation of new parties and contesting elections) to mobilizational tactics, like popular demonstrations, investor strikes, media campaigns, and the mobilization of international support against Left governments, including, at times, advocating for economic sanctions. In a handful of cases, national right-wing movements have also resorted to semi- or extra-constitutional tactics, in some cases allying themselves with elements of the armed forces to carry out "hard" coups, as happened in Venezuela in 2002 and more successfully in Honduras in 2009. Of increasing concern, however, are what activists and analysts have termed "soft" or "smart" coups. [For more see the roundtable on "21 st Century Golpismo" in this issue of the Report.] To date, these assertions of rightwing power through the legally-questionable actions of judges and legislators have involved a combination of institutional and mobilizational strategies, thus giving an air of legitimacy to impeachment processes against sitting Left presidents, as happened in Paraguay in 2012 and more recently in Brazil in 2016.

The above strategies to challenge the Left are not necessarily mutually exclusive; they have often been used together, to greater or lesser degrees, depending on the national context. However, in the last decade, what has united right-wing efforts is their ultimate aim of removing Left governments from power and replacing them with regimes that advocate a return to neoliberalism. In recent months, this has meant a type of neoliberalism which is deeply embedded in national and transnational power structures, making it much more difficult for future Left governments to reverse neoliberal policies in the future. The new president of Brazil, Michel Temer, for example, plans to install a deficit brake for 20 years, thus limiting future governments from financing social programs, which were key to the PT's rise. Meanwhile, during a visit by U.S. President Barack Obama in March 2016, Mauricio Mach, 
the new right-of-center president of Argentina, was rumored to have signaled his wish for Argentine participation in the Trade In Services Agreement, or TISA, a shadowy global trade treaty that many free trade skeptics see as an attempt to isolate the BRICS. Once installed, these efforts could limit the prospects for progressive, Left alternatives to prosper- even if Left governments regain power.

\section{"A Strong but Restricted State"}

Right-wing policy choices have not emerged in a vacuum; rather they reflect deeply held beliefs among elites in Latin American civil society In late 2011 and early 2012, I spent four months carrying out more than 60 interviews with elites in four countries in South America-Argentina (November 2011), Chile (December 2011), Colombia (January 2012), and Venezuela (February 2012). Subjects interviewed were drawn from Right-oriented political parties, major liberal-oriented think tanks, business associations, private institutions of higher education, and the Catholic Church, among others. In these interviews, I wanted to see if and how regional elites had been influenced by Left policies over the last decade and half-many of which have promoted increased state intervention in the economy and lessened class, ethnic, and gender inequalities in the process. What I found, however, was very much in line with previous studies on Latin American parliamentary elites by Manuel Alcántara Saéz and his colleagues at the University of Salamanca as well as Elisa Reis's studies of business elites in Brazil. That is, despite the fact that many social indicators suggest significant progress under the leadership of the Latin American Left over the last decade and half, Latin American elites continue to view neoliberal policies as the best means to make the economy "work" and ensure social mobility-regardless of one's gender, class, or ethnicity

So when asked, for example, about the balance between the state and the market, my interview subjects consistently argued that state intervention in the economy-and indeed in society, more broadly-must be kept to a minimum, if it should exist at all. One individual, a director of an important Argentine landowners' association, for example, argued in November 2011 that the state should only have competencies in "security, justice, health and education." In other words, to use a phrase coined by Maria Corina Machado, a prominent opposition politician in Venezuela that I interviewed in Februar)? 2012, the state should be "strong but restricted." Basic public services, primarily health and education, should be provided, most of my respondents agreed, but simultaneously, there was a consensus that such services do not necessarily need to be provided by the state. What's more, across the board, the elites I spoke with maintained that welfare programs should be tightly targeted to the poorest in society, with the rest having to fend for themselves in the market. The rationale here is not to lessen socio-economic inequality but rather to facilitate individual participation in the market, with employment, preferably in the private sector, as elites' main goal. Hence, Rolf Luders, a prominent economist in Chile and an ex-minister from the Pinochet era, insisted to me in an interview I held with him in Santiago in December 2011 that "if the guy is poor and doesn't have enough to live decently, I think society probably has a moral obligation to help." But, as Luders asks, "How do you help the poor the best? By growing income growth." If help is given, the Chilean economist adds, it "must be tightly focused on those who most need it."

Indeed, the ultimate objective of many Latin American elites is to still have no social policy at all. At least that is what Julio Borges, another prominent Venezuelan opposition politician, contended when I spoke to him in Caracas in February 2012. "How is that achieved?, Borges asked rhetorically, "With...productivity, investment, diversification of the economy," he said. Borges drew a vivid analogy with regard to the Venezuelan government's social "missions," set up first by President Chávez to provide the poor with health, education, and other social welfare services. "Suppose that you fall in the river and you don't know how to swim and you are drowning. The Missions are the lifebelts which are launched so that you can float and save yourself," Borges told me. "The difference between the [Chavista] government and us," he continued, "is that we are clear that the final aim is to get you out of the river. For the government the ultimate aim is that you stay floating in the river, dependent on the 
government." By this reading, social security is a temporary measure provided only in extreme circumstances. State help is merely a trap and only the private sector can truly set you free.

To greater or lesser extents, inequalities based on class, race, and gender were acknowledged by most of my interview subjects in all four countries. However, the overall emphasis remained on the individual, who, with the correct guidance, support, and personal effort-and regardless of race, class, or gender-are believed by conservative thinkers and politicians to be capable of participating in national life to achieve success. Indeed, as a member of Pensamiento Conservador (Conservative Thinking), a liberal discussion group in Colombia, told me in Bogotá in January 2011 , only "equality before the law" is necessary for social advancement. "There is no need for [granting] privileges or more rights than anyone else," he said, referencing his disdain for gender quotas or affirmative action for ethnic minorities.

Again, some interviewees disbelieved in disadvantage due to gender. For example, a female Argentine academic who I interviewed in Buenos Aires in November 2011 expressed her belief that "most women can choose to work or to stay at home.. .to care for the children." Working for most women, in this view, was simply a choice to be made, and not an economic necessity, or indeed a right. That said, she and others did recognize that poorer women may not have such a choice and would have to work to make ends meet, but here too, childcare was best provided for in the market or by market actors. Rolf Luders, the already-cited Chilean economist suggested a voucher system for poor women to buy childcare sendees from private companies. Others I spoke with pointed to special employer/employee agreements as a solution to childcare access. Rarely did people suggest that such sendees be provided directly by the state, and less still as a right. Finally, gender was, for some, simply not an urgent issue at all. For example, a female member of the Center for the Diffusion of Economic Knowledge for Liberty (CEDICE), a free-market think tank based in Caracas, Venezuela, told me in February 2012 that her country simply had "other more important priorities" to deal with than gender inequality.

On the issue of ethnic inequality, several of the elites I spoke with acknowledged the existence of such problems, but for the most part demonstrated little appetite for using state intervention to rectify them. In Colombia, members of Pensamiento Conservador who participated in my focus group argued that indigenous communities are treated as "vulnerable groups" when, in fact, they are not. "They present themselves as victims," one of my subjects told me in Bogotá. Another member of Colombia's economic elite, the then president of the Colombian Agricultural Society (SAC), Rafael Mejia, suggested to me in an interview that the lands in indigenous reserves are not "for contemplating the sunset," adding that indigenous peoples are "business people," even if they themselves "did not yet know it." Hence, according to Mejia, education was needed to help unleash the innate entrepreneurialism of marginalized groups, signaling the widely held belief amongst respondents that capitalism represented a sort of "natural" state for humankind. Similarly, one member of a military support group I met with in Buenos Aires, Argentina in November 2011, the Unión de Promociones (Union of Promotions), argued that the "only solution" to most of Argentina's problems-everything from populism to indolence to corruption-was "education." "For that reason," this focus group participant told me, change would "be a slow process, if it happens at all."

Despite some differences around levels of state provision, discourse among right-leaning and liberal actors in politics, civil society, and business in Chile, Venezuela, Colombia, and Argentina reflects a remarkably coherent view of the type of society that the region's resurgent Right desires: one which remains grounded in marketled initiative and in which inequalities are of scant state concern-or at least are seen as remediable through the market. In other words, state action is permissible but only if directed toward the very poorest. As one member of a Chilean think-tank stated, "The state cannot maintain all of society." In general, the strict condition that many rightwing intellectuals and elites place on government assistance is that those who benefit from it must return as promptly as possible to the market. As the Brazilian political scientist Elisa Reis points out in her work, while elites 
may envisage a role for the state in supporting the poor, they absolve themselves of any further responsibility to support this work through, say, increased taxation.

\section{From Right Strategies to Left Responses}

In this environment, how then might the Left respond to the continued persistence of neoliberalism among Latin American elites and the imminent application of such ideas by new Right governments? I would contend that responses are needed along three distinct strategic areas: organizational, programmatic, and discursive. First, the Left needs to focus on its own organization, seeking a new balance between grassroots power and political leadership. To be sure, both are necessary, but during the "pink tide" moment too much emphasis was placed on the latter, often to the detriment of the former.

Second, there needs to be a regrouping of the Left around a basic set of unifying ideas-a "singular socialist horizon" as Roger Burbach, Michael Fox, and Federico Fuentes term it in their 2013 book, Latin America's Turbulent Transitions. This will require the definition of a new and more vigorous economic model, which leaves behind the divisiveness, inequities, and environmental dangers of natural resource-based extractivism. Simultaneously, such a vision should provide innovative and effective solutions to increase and enhance the political and social inclusion of the region's popular majorities, including around race, gender, and ethnic inequality. Moreover, a "new new Left" needs to take more seriously issues that the Right has capitalized on in recent years, such as popular concerns about citizen security, crime, economic efficiency, and corruption.

Finally, a new discursive strategy needs to be developed by the Left. This will involve building a unifying counterhegemonic narrative that can attract and engage voters. Such a discourse should exploit divisions in the Rightbetween radicals and moderates, namely-but it also should involve a reassessment of the Left's communicative structures, both assessing its current capacities and constructing new forums of exchange through Left think tanks and alternative media. In all cases, such discussions should focus on remaking Left movements, rather than the Left-led state. Most importantly, a new Left strategy needs to highlight what it does well, in helping rectify class, gender, and racebased inequalities, for example. And it should have a transnational component to it, linking up with new Left alternatives in Europe and the U.S., such as Syriza in Greece, Podemos in Spain, and resurgent Left movements in North American politics-thus augmenting its reflexive capacity and international weight.

Some elements of this possible future can already be found in protest movements that sprung up around the region earlier this decade. For example, Jean Grugel and Jewellord Nem Singh argue in their 2015 article "Protest, Citizenship and Democratic Renewal: The Student Movement in Chile," that the student protests taking place there beginning in 2006 seek to replace neoliberal forms of citizenship based on individualized consumption with ones based on rights and welfare. Many of the discourses and tactics used by Chile's students have resonated deeply with the Chilean people, and, quite significantly, the movement produced new forms of popular leaderships. One must look no further than the country's national congress, where former student leaders Camila Vallejo and Giorgio Jackson now serve as national deputies.

Another example are the protests in Brazil, which, starting in 2013, brought students and youth organizations to the streets to demand improved public services and less corruption in public life. Views on these protests are more divided than the Chilean case, with, for example, London-based scholar Alfredo Saad Filho arguing that they were manipulated by the Right in order to remove Dilma Rousseff from power-despite the validity of some of their initial claims. Others, such as anthropologist James Holston, have viewed these protests differently, suggesting they offer the beginnings of a new form of urban direct democracy out of which new types of organization and leadership may spring. Similarly, in Venezuela, the crisis in the ruling United Socialist Party of Venezuela (PSUV) is 
opening up discussion on the Left, particularly among more radical sectors associated with Chavismo, in outlets such as Rebelion.org orAporrea.org. In other words, there is an awareness among young Latin Americans of the need for renovation of ideas and leadership. At the present moment, however, it is still too early to say precisely where such discussions will lead. CD

\section{Sidebar}

in the last decade, what has united right-wing efforts is their ultimate aim of removing Left governments from power and replacing them with regimes that advocate a return to neoliberallsm.

\section{Sidebar}

There is an awareness among young Latin Americans of the need for renovation of ideas and leadership.

\section{AuthorAffiliation}

Barry Cannon teaches in the Department of Sociology at Maynooth University in Ireland. He is the author of The Right in Latin America: Elite Power, Hegemony and the Struggle for the State (Routledge, 2016).

\section{DETAILS}

$\begin{aligned} & \text { Subject: } \\ & \text { Citizenship; Wage \&price controls; Conservatism; Neoliberalism; Power; Democracy; } \\ & \text { Privatization }\end{aligned}$
$\begin{aligned} & \text { Location: } \\ & \text { Publication title: }\end{aligned}$
Volume:
NACLA Report on the Americas; New York
Issue:

Pages: $\quad 328-333$

\begin{tabular}{ll}
\hline Number of pages: & 6 \\
\hline Publication year: & 2016 \\
\hline Publication date: & Winter 2016 \\
\hline Section: & REPORT \\
\hline Publisher: & Taylor \&Francis Ltd. \\
\hline Place of publication: & New York \\
\hline Country of publication: & United Kingdom, New York \\
\hline Publication subject: & Business And Economics--International Commerce, Sociology, Political Science-- \\
\hline
\end{tabular}


ISSN:

10714839

Source type: $\quad$ Magazines

Language of publication: English

Document type: $\quad$ Feature

DOI: $\quad$ http://dx.doi.org/10.1080/10714839.2016.1258275

ProQuest document ID: $\quad 1866259476$

Document URL: $\quad$ https://search.proquest.com/docview/1866259476?accountid=12309

Copyright: $\quad$ Copyright Taylor \&Francis Ltd. Winter 2016

Last updated: $\quad$ 2017-11-24

Database: Social Science Premium Collection

\section{LINKS}

Search for full-text at Maynooth University

Database copyright (C 2019 ProQuest LLC. All rights reserved.

Terms and Conditions Contact ProQuest 